VERTAISARVIOITU

KOLLEGIALT GRANSKAD

PEER-REVIEWED

www.tsv.fi/tunnus

\title{
IKÄÄNTYNEIDEN SUOMENPUHUJIEN SEMANTTINEN SANASUJUVUUS \\ ELÄINKATEGORIASSA
}

Niina Rinne*, Sivupersoona Oy

Meri Hursti*, Sivupersoona Oy

Anna-Maija Korpijaakko-Huuhka, Tampereen yliopisto

Leena Rantala, Tampereen yliopisto

* Kirjoittajat jakavat ykköskirjoittajuuden

Tutkimuksessa tarkasteltiin 30 tyypillisesti ikääntyneen 80-92-vuotiaan puhujan suoriutumista semanttisessa sanasujuvuustehtävässä. Heidän tuli luetella minuutin ajan eläimiä tarkoittavia sanoja. Tuotoksesta laskettiin oikein tuotettujen sanojen, klustereiden ja vaihtojen sekä toistojen ja kategorian ulkopuolisten sanojen määrät. Suoritusta tarkasteltiin myös 15 sekunnin aikajaksoissa. Lisäksi tarkasteltiin iän, sukupuolen ja koulutuksen yhteyttä sanasujuvuusmuuttujiin.

Tutkittavat tuottivat keskimäärin 18,2 sanaa, joista yli puolet (65\%) ensimmäisen puolen minuutin aikana. Nuoremmat tutkittavat (80-84-vuotiaat) tuottivat merkitsevästi enemmän sanoja oikein kuin vanhemmat. Puhujat eivät tuottaneet annetun kategorian ulkopuolisia sanoja. Sanoista muodostui keskimäärin neljä semanttista klusteria, joiden laajuus oli keskimäärin 3,5 sanaa. Toiston osuus sanojen kokonaismäärästä oli keskimäärin $6,5 \%$. Tutkimuksen perusteella yli 80-vuotiaiden ihmisten semanttisen sanasujuvuuden arvioinnissa huomiota tulisi kiinnittää oikein tuotettujen sanojen määrään, kategorian ulkopuolisiin sanoihin sekä toistojen määrään ja laatuun.

Avainsanat: ikääntyminen, kielelliskognitiiviset taidot, sanahaku, semanttinen sanasujuvuus

\section{JOHDANTO}

Euroopan väestö ikääntyy nopeasti (Eurostat, 2016, 2019), Suomen erityisen nopeasti (Parjanne, 2004). Erittäin iäkkäiden (yli 80-vuotiaiden) ihmisten osuuden väestöstä arvioidaan lähes kolminkertaistuvan nykyisestä 5,6 prosentista 14,6 prosenttiin vuosisa- dan loppuun mennessä (Eurostat, 2019). Kun ihminen elää erittäin vanhaksi, fysiologiset ja anatomiset muutokset heikentävät hänen toimintakykyään, viestintäkyky mukaan lukien (Korpijaakko-Huuhka \& Klippi, 2017). Kielellisiä muutoksia alkaa ilmetä 70-80

Kirjoittajien yhteystiedot:

Niina Rinne

niina.rinne@sivupersoona.com
Meri Hursti

meri.hursti@sivupersoona.com 
vuoden iässä; tyypillisimpiä ovat sananlöytämisen vaikeudet (Cahana-Amitay \& Albert, 2014; Nicholas, Connor, Obler \& Albert, 1998). Ne voivat kertoa myös patologisista muutoksista, esimerkiksi alkavasta muistisairaudesta (Haugrud, Crossley \& Vrbancic, 2011). Patologisten muutosten erottaminen tyypillisistä ikämuutoksista on usein vaikeaa, koska tietoa tyypillisesti ikääntyvien erittäin vanhojen ihmisten kielelliskognitiivisten taitojen muutoksista on vähän (Hautala, 2013, s. 19; Pekkala, 2011; Stolwyk, Bannirchelvam, Kraan \& Simpson, 2015).

Tämän tutkimuksen tarkoituksena on lisätä tietoa tyypillisesti ikääntyneiden 80 -vuotiaiden ja sitä vanhempien suomenkielisten puhujien kielelliskognitiivisista kyvyistä tarkastelemalla heidän suoriutumistaan tehtävässä, jossa he palauttivat mieleensä mahdollisimman monta eläintä tarkoittavaa sanaa minuutin aikana. Tehtävän on todettu erottelevan herkästi ja luotettavasti tyypillisiä ikääntymiseen liittyviä kielelliskognitiivisia muutoksia patologisista muutoksista (Henry \& Crawford, 2004; Stolwyk ym., 2015). Tässä artikkelissa ikääntymismuutoksia lähestytään pääosin neuropsykologisina ja neurolingvistisinä ilmiöinä.

\subsection{Ikääntymisen kielelliskognitiviset muutokset}

Terveeseen ikääntymiseen liittyvien hermoverkoston anatomisten ja fysiologisten muutosten seurauksena ikääntyvän ihmisen kielelliskognitiiviset kyvyt heikkenevät yksilöllisesti, eikä tyypilliseen ikääntymiseen liity afaattisia häiriöitä (Korpijaakko-Huuhka \& Klippi, 2010; 2017). Kielelliskognitiivisen ikääntymisen on todettu olevan epäsymmetristä: puheen ymmärtämisen kyvyt säilyvät puheentuottoa paremmin (Burke \& Graham, 2012; Marini \& Andreetta, 2016). Sanaston puolestaan on todettu jopa kasvavan erittäin korkeaan ikään asti (Maxim \& Bryan, 1994, s. 34; Verhaegen, 2003). Iän myötä ihmisen kognitiivinen prosessointi kuitenkin hidastuu asteittain (Dennis \& Cabeza, 2008, s. 11; Wingfield, 2000). Esimerkiksi reaktioajat pidentyvät, ja sanojen tunnistaminen ja nimeäminen hidastuvat (Burke \& Shafto, 2008; Mortensen, Meyer \& Humpreys, 2007). Tiedonkäsittelyn hidastuminen koskee enemmän tietoisia, joustavia (fuent) kognitiivisia prosesseja kuin automaattisia, kiteytyneitä (crystallized) yliopittuja prosesseja (Burke \& Shafto, 2008, s. 402; Hautala, 2013, s. 29). Tiedon joustava prosessointi onkin menestyksellisen suoriutumisen edellytys sanasujuvuustehtävässä (Roca ym., 2012).

Ikääntyessä myös muistitoiminnot heikentyvät lieväasteisesti, erityisesti episodinen eli tapahtumamuisti ja työmuisti (Braver \& West, 2008; Thornton \& Light, 2006). Työmuistin kapasiteetti (muistettavan aineksen määrä) pienenee ja prosessointi (tiedon muokkaus ja yhdistely pitkäkestoisen muistin kanssa) hidastuu (Abrams \& Farrell, 2010; Cowan, 2010). Näin käy erityisesti, kun ikäihmisen tulee samanaikaisesti sekä pitää tietoa mielessään että aktiivisesti käsitellä sitä. Työmuistijärjestelmä liittyy läheisesti tarkkaavuuteen ja eksekutiivisiin toimintoihin (Braver \& West, 2008). Eksekutiiviset eli toiminnanohjauksen prosessit mahdollistavat kognitiivisesti monimutkaisten ja tavoitteellisten toimintojen suunnittelun, koordinoinnin ja monitoroinnin (Shao, Janse, Visser \& Meyer, 2014; Whiteside ym., 2016). Toiminnanohjaukseen liitetään myös kyky estää (inhiboida) kontekstiin epäsopivan tai epäolennaisen kielellisen aineksen valintaa (Hasher \& Zacks, 1988; Sylvain-Roy, Lungu \& Belleville, 2015; Zacks \& Hasher, 1997). Inhiboinnin hankaluudet voivat ilmetä esimerkiksi tehottomina tai virheellisinä sanan valinta- ja hakuprosesseina. Semanttisen sanasujuvuuden tehtävästä suoriutumiseen vaaditaan toiminnanohjauksen ja työmuistin saumatonta yhteistyötä 
(Shao ym., 2014; Pekkala, 2012; Whiteside ym., 2016).

Neurolingvistisestä näkökulmasta tyypilliset ikääntymismuutokset aiheutuvat kielen merkitykseen sekä sanojen äänneasuun liittyvien neuroniverkostojen aktivaation heikentymisestä ja niukentumisesta, mikä haittaa semanttisen ja fonologisen tiedon saamista aktiiviseen käyttöön (Burke \& Graham, 2012; Mortensen ym., 2007; Obler \& Pekkala, 2008). Käytännössä tämä voi ilmetä sananlöytämisen vaikeuksina, jotka hankaloittavat suoriutumista semanttisesta sanasujuvuustehtävästä (Abrams \& Farrell, 2010; Burke \& Graham, 2012).

Tyypilliset ikääntymismuutokset tapahtuvat hitaasti, ja aivojen hermoverkoston plastisuus mahdollistaa neuraalisten toimintojen uudelleenjärjestäytymistä ikääntymismuutosten myötä (Ansado, Marsolais, Methqal, Alary \& Joanette, 2013; Fjell, Evoy, Holland, Dale \& Wavhovd, 2014). Eritoten arjen tutuissa kommunikointitilanteissa iäkkäät ihmiset ovatkin edelleen varsin sujuvia vuorovaikutuskumppaneita (Kemper \& Kemtes, 2000; Wingfield \& Stine-Morrow, 2000). Vuorovaikutuksen sujuvuuteen vaikuttavat myös iäkkään ihmisen sosiaaliseen, kulttuuriseen ja ympäristöön liittyvät kokemukset (Muskett, Body \& Perkins, 2013; Pekkala, 2012). Näillä on oma vaikutuksensa myös semanttisessa sanasujuvuustehtävässä suoriutumiseen.

\subsection{Semanttinen sanasujuvuus}

Sanasujuvuus tarkoittaa yksilön kykyä hakea nopeasti sanoja mentaalileksikosta ('sisäisestä sanastosta'; Levelt, 1989, s. 182-183, 232). Sanasujuvuutta arvioidaan tehtävillä, joissa yksilö tuottaa puhuen tai kirjoittaen tietyssä ajassa tiettyjen sääntöjen mukaan mahdollisimman monta sanaa (Pekkala, 2012; Shao ym., 2014). Säännöt voivat olla semanttisia (kategoria rajattu; Capitani, Laiacona
\& Barbarotto, 1999; Crowe, 1998; Troyer, Moscovitch \& Winocur, 1997), fonologisia (alkuäänne määrätty; Capitani, Laiacona \& Basso, 1998; Rosen, 1980) tai verbien tuottoa edellyttäviä (Pekkala, 2004; Östberg, Fernaeus, Hellström, Bogdanovic \& Wahlund, 2005). Tässä artikkelissa semanttisella sanasujuvuudella tarkoitetaan yksilön kykyä tuottaa merkityssuhteiltaan samaan kategoriaan (eläimet) kuuluvia sanoja minuutin aikana.

Kategorian ulkopuolisten sanojen (intruusioiden) ilmeneminen ja samojen sanojen toisto (perseveraatio) kertovat kielelliskognitiivisen prosessoinnin ongelmista semanttisessa sanasujuvuustehtävässä (Azuma, 2004; Pakhomov, Eberly \& Knopman, 2018; Pekkala, 2012). Terveillä tutkimushenkilöillä intruusiot ovat erittäin harvinaisia, mutta niiden on todettu liittyvän moniin neurologisiin sairauksiin ja syndroomiin (Pekkala, 2004, s. 109-111; 2012; Suhr \& Jones, 1998; Tröster, Salmon, McCullough \& Butters, 1989). Myös perseveraatio on terveillä tutkimushenkilöillä harvinaista, mutta iän myötä se voi lisääntyä (Gruenewald \& Lockhead, 1980; Pekkala, 2012; Ramage, Bayles, HelmEstabrooks \& Cruz, 1999; Ruff, Light, Parker \& Levin, 1997). Terveet tutkimushenkilöt toistelevat aiemmin tuottamiaan sanoja tyypillisesti muutamien uusien sanojen jälkeen (lehmä, sika, vuobi, lehmä...), kun taas neurologisiin sairauksiin liittyessään perseveraatio voi ilmetä jatkuvana toistona (lehmä, lehmä, lehmä...) tai juuttumisena edelliseen puhetuotokseen, esimerkiksi tutkimustilanteessa edelliseen tehtävänantoon (Moses, Nickels \& Sheard, 2007; Pekkala, 2012; Pekkala, Albert, Spiro \& Erkinjuntti, 2008). Perseveraation laatu (toistuva, jatkuva tai juuttuva; Albert \& Sandson 1986; Sandson \& Albert, 1987) ja märä voivatkin toimia tyypillisen ja patologisen ikääntymisen erotusdiagnostiikan tukena tai pohdittaessa tyypilliseen ikääntymiseen liittyvien muutosten taustal- 
la vaikuttavia kielelliskognitiivisia tekijöitä, kuten työmuistin toimintaa (Azuma, 2004; Pakhomov ym., 2018; Ramage ym., 1999).

Sanasujuvuustehtävässä voidaan lisäksi laskea, miten oikein tuotetut sanat jakautuvat käytettyyn aikaan, esimerkiksi 60 sekunnin tehtävässä 15 sekunnin jaksoille eli minuutin neljänneksille (Crowe, 1998; Demetriou \& Holzer, 2017; Fernaeus \& Almkvist, 1998). Tyypillisesti kielessä usein esiintyviä (korkeafrekventtisiä) sanoja tuotetaan eniten ensimmäisen neljänneksen aikana, jonka jälkeen ihminen alkaa tuottaa harvemmin esiintyviä sanoja, jolloin myös sanojen tuottomäärä hiipuu (Demetriou \& Holzer, 2017; Fernaeus \& Almkvist, 1998; Raboutet ym., 2010).

Semanttista sanasujuvuutta arvioidaan myös tarkastelemalla sanojen välisiä merkityssuhteita (Troyer ym., 1997). Sanaedustumien ajatellaan muodostavan mentaalileksikossa semanttisia kategorioita (Goñi ym., 2011; Levelt, 1989, 182-183), jotka sanasujuvuustehtävässä ilmenevät näihin kategorioihin kuuluvien sanojen ryppäinä eli klustereina (Pekkala, 2004, s. 67; Troyer ym., 1997; Troyer, Moscovitch, Winocur, Leach \& Freedman, 1998). Semanttinen klusteri muodostuu Troyerin työryhmän (1997) laskentamallin mukaan vähintään kahdesta samaan kategoriaan kuuluvasta sanasta; esimerkiksi harakka ja varis muodostavat klusterin linnut. Kun puhuja ei enäälöydä yhteen semanttiseen (ala)kategoriaan kuuluvia sanoja, hän voi vaihtaa hakustrategiaa eli valita toisen (ala) kategorian. Sujuvan vaihtamisen kategoriasta toiseen ajatellaan ilmentävän toiminnanohjauksen tehokkuutta (Troyer ym. 1997). Klustereiden kokonaismäärän ajatellaan kertovan puolestaan kyvystä käyttää tehokkaasti sanahakustrategioita ja klusterin keskimääräisen koon kyvystä hakea muistista tietyn alakategorian sanoja (Pekkala, 2012; Pekkala, 2004, s. 88; Troyer, 2000; Troyer ym., 1997).

Klusterin koko voidaan laskea eri tavoilla.
Tässä tutkimuksessa noudatettiin Troyerin työryhmän (1997) mallia, jonka mukaan sanaryppään ensimmäistä sanaa ei lasketa mukaan; esimerkiksi kolmen sanan klusterin kooksi tulee näin kaksi sanaa. Yhtä universaalia tapaa määritellä esimerkiksi juuri eläinkategorian alakategorioita ei ole, vaan ne muodostuvat sanasujuvuustehtävässä aina aineistolähtöisesti ja heijastavat yksilön omaan elämänkokemukseen - kotimaahan, kieleen, kulttuuriin ja elinympäristöön - pohjautuvia semanttisia kategorioita, joita vain ihminen itse voi märitellä luotettavasti (esim. Body \& Muskett, 2013; Mayr, 2002; Muskett ym., 2013; Pekkala, Goral, Hyun, Obler, Erkinjuntti \& Albert, 2009; Woods, Wyma, Herron \& Yund, 2016).

\subsection{Ikääntyminen ja semanttinen sanasujuvuus}

Ikääntyneet ihmiset tuottavat sanasujuvuustehtävässä tyypillisesti vähemmän sanoja kuin nuoremmat, ja oikein tuotettujen sanojen määrän onkin havaittu laskevan lineaarisesti iän funktiona (Taler, Johns \& Jones, 2019; Tombaugh, Kozak \& Rees, 1999; Troyer, 2000; Troyer ym., 1997; Vaughan, Coen, Kenny \& Lawlor, 2016). Toisaalta puhevirran sujumattomuuksien, kuten toiston, on todettu lisääntyvän iän myötä (Ramage ym., 1999; Woods ym., 2016). Ikääntymismuutokset eivät näytä vaikuttavan klustereiden määrään, mutta vaihtojen määrä vähenee, mikä kasvattaa klustereiden keskikokoa (Troyer, 2000; Troyer ym., 1997). Koulutuksen ja sukupuolen vaikutus semanttisen sanasujuvuustehtävän tulokseen on ristiriitainen. Osassa tutkimuksia yhteys on havaittu (esim. Capitani ym., 1999; Zarino, Crespi, Launi \& Casarotti, 2014), toisissa selvä vaikutus puuttuu (esim. Stolwyk ym., 2015; Tombaugh ym., 1999; Troyer, 2000). Myös kulttuuriset tekijät voivat vaikuttaa tuloksiin, minkä vuoksi eri maissa tarvittaisiin kuhunkin kulttuuriin 
ja kieleen perustuva normatiivinen tietokanta (Ardila, Ostrosky-Solís \& Bernal, 2006; Kim, Kim, Wolters, MacPherson \& Park, 2019; Tallberg, Ivachova, Jones Tinghag \& Östberg, 2008; Zarino ym., 2014).

Tutkimuksemme tavoitteena oli selvittää, (1) kuinka paljon oikein tuotettuja sanoja ikääntyneet suomenkieliset puhujat tuottavat semanttisessa sanasujuvuustehtävässä, (2) kuinka paljon erilaisia klustereita ja vaihtoja he tekevät ja (3) paljonko he tuottavat kategorian ulkopuolisia sanoja ja toistoja. Lisäksi mittasimme, (4) miten semanttisessa sanasujuvuustehtävässä tuotetut sanat jakautuvat minuutin neljänneksille. Lopuksi tutkimme, (5) onko iällä, sukupuolella ja koulutustasolla yhteyttä sanasujuvuustehtävässä suoriutumiseen.

\section{MENETELMÄT}

\subsection{Tutkimushenkilöt}

Tutkimukseen haettiin osallistujia Pirkanmaalta yhden tutkijan tuttavapiiristä ja kahden harrastekerhon osallistujista (ks. Hursti, 2018). Valintakriteereitä oli kolme: äidinkielenä suomi, ikä 80 vuotta tai enemmän ja subjektiivisesti arvioituna hyvä neurologinen terveydentila. Tällä mukavuusotannalla potentiaalisia tutkittavia saatiin 33. Heihin otettiin yhteyttä puhelimitse, ja puhelinhaastattelussa varmistettiin erityisesti, että heillä ei ollut lääkärin diagnosoimaa muistisairautta tai aivoverenkiertohäiriötä. Kolme henkilöä jätettiin tutkimuksen ulkopuolelle diagnoo- siensa perusteella: yksi sairastetun aivoverenkiertohäiriön, yksi Parkinsonin taudin ja yksi dementian takia. Tutkimushenkilöitä kertyi siten yhteensä 30 (Taulukko 1).

Tutkittavien kielellisiä kykyjä kartoitettiin diagnostisella afasiatestillä (Western Aphasia Battery, WAB; suomenkielinen versio Pietilä, Lehtihalmes, Klippi \& Lempinen, 2005). Viidellä tutkittavista afasiaosamäärä $(\mathrm{AO})$ jäi alle ns. afaattisuuskriteerin (93,8 pistettä). Lisäksi yhden henkilön näkövamma esti häntä suoriutumasta kuvan kuvailutehtävästä; näin AO:ä ei pystytty laskemaan. Päädyimme ottamaan nämä henkilöt mukaan tutkimukseen ensinnäkin siksi, ettei WAB-testin afasiaosamäärä ollut tutkittavien valinnassa poissulkukriteerinä. Toiseksi WAB-testin käsikirja ei esitä poikkeavan suorituksen rajaa erittäin iäkkäille henkilöille. Emme myöskään löytäneet perusteita olettaa, että terveesti ikääntyneiden tutkittavien afaattisuuskriteerin alittava afasiaosamäärä ilmentäisi yksiselitteisesti kielellistä häiriötä, esimerkiksi lievään kognitiiviseen heikentymiseen viittaavia määrittelemättömiä kielelliskognitiivisia oireita (ks. Petersen, Doody, Kurz, Mohs, Morris, Rabins ym., 2001). Kyse saattoi olla ikääntymiseen liittyvästä suorituskyvyn hetkittäisestä vaihtelusta tai kognitiivisen toimintakyvyn hajonnan lisääntymisestä vanhusväestössä (Ylikoski, Ylikoski, Keskivaara, Tilvis, Sulkava \& Erkinjuntti, 1999). Tässä tutkimuksessa oli tärkeätä kartoittaa juuri tavanomaista iän tuomaa suoriutumisen vaihtelua, ja pidimme kaikki 30 tutkittavaa mukana tutkimuksessa.

TAULUKKO 1. Tutkittavat.

\begin{tabular}{|l|l|l|l|l|}
\hline & Ikä (vuotta) & WAB AO (pist.) & Koulutustaso & Ikm \\
\hline & $\boldsymbol{n = 3 0}$ & $\boldsymbol{n = 2 9}$ & & \\
\hline Keskiarvo & 85,1 & 96,4 & Kansakoulu & 15 \\
\hline Mediaani & 84,5 & 96,8 & Ammattikoulu/lukio & 11 \\
\hline Keskihajonta & 3,8 & 2,4 & Korkeakoulu/Yliopisto & 4 \\
\hline Vaihteluväli & $80-92$ & $90,2-100$ & Yhteensä & 30 \\
\hline
\end{tabular}


Tutkimukseen osallistuneista suurin osa oli naisia (77\%). Puolet tutkittavista oli tutkimushetkellä iältään 80-84-vuotiaita ja puolet 85-92-vuotiaita. Tutkimushenkilöiden koulutustausta vaihteli.

\subsection{Aineisto ja analyysi}

Eläinsanasujuvuustehtävä kuuluu WAB-testin nimeämisen osa-alueen tehtäviin. Siinä tutkittavaa pyydettiin tuottamaan minuutin aikana niin monta eri eläintä tarkoittavaa sanaa kuin mahdollista. Aineiston keräsi yksi tutkija yhden tutkimuskäynnin aikana tutkimushenkilöiden kotona (yhtä lukuun ottamatta). Aineisto tallennettiin audio(Olympus Linear PCM Recorder LS-5) ja video- (Panasonic HC-V750 Progressive) tallenteina. Suoritukset litteroitiin Praatohjelman avulla (Version 6.1.04, Boersma \& Weenink, 2005).

Litteroinneista laskettiin tunnuslukuja Troyerin ym. (1997) laskentamallin mukaan. Oikein tuotettujen sanojen määrä saatiin poistamalla sanojen kokonaismäärästä toistot ja intruusiot. Mallista poiketen toistoksi ${ }^{1}$ ei laskettu saman alakategorian sanoja, joilla tutkittava tarkoittaa eri asioita (esimerkiksi vasikoinut lehmä vs. vasikoimaton hieho) (Ruffym., 1997). Tätä ratkaisua puolsi se, että tutkimukseen osallistuneet henkilöt asuivat maaseudulla ja olivat saaneet elantonsa pääosin maataloudesta. Heille eri ikäiset ja eri sukupuolta edustavat saman eläinlajin yksilöt olivat semanttisesti keskenään erilaisia käsitteitä. Oikein tuotettujen sanojen joukkoon päädyimme hyväksymään alakategoriaan kuuluvien sanojen (bieho, vasikka) lisäksi myös yläkäsitteet (esim. lehmä) (Lopes, Brucki, Giampaoli \& Mansur, 2009; Tallberg, ym., 2008).

\footnotetext{
${ }^{1}$ Troyer ym. (1997) pitävät toiston määritelmänä saman sanan täsmällistä toistamista ja sanan synonyymien käyttöä (esimerkiksi hevonen ja polle) sekä eläinkategoriassa eri sukupuolta ja eri ikää ilmentäviä sanoja (kuten tamma, ori ja varsa).
}

Myös klusteroinnissa otettiin huomioon tämän puhujaryhmän tuottamat itselleen luonnolliset sanaryhmät (Gruenewald \& Lockhead, 1980; Hoffman \& Lambon Ralph, 2013; Troyer, 2000; Troyer ym., 1997), esimerkiksi tiettyjen eläinten esiintyminen tutkittavien omassa lähiympäristössä tai saman eläimen kuuluminen puhujasta riippuen useampaan eri ryhmään (Ardila ym., 2006; Kavé, 2005; Kavé, Kigel \& Kochva, 2008; Kim ym., 2019; Pekkala, 2012, s. 620; Tallberg ym., 2008). Siinä missä yksi puhuja siis saattoi luetella oravan osana Suomen luonnonvaraisten eläinten kategoriaa, toinen puhuja tuotti oravan kotipiirin eläinten klusteriin.

Klusterin muodosti pienimmillään kaksi peräkkäistä samaan alakategoriaan kuuluvaa sanaa (Haugrud ym., 2011; Tallberg ym., 2008; Troyer ym., 1997). Klusterin keskimääräisen koon laskennassa yksittäinen sana sai arvon 0 , kaksi sanaa arvon 1 , kolme sanaa arvon 2 ja niin edelleen (Troyer, 2000). Arvojen summa jaettiin klustereiden määrällä mukaan lukien myös yksittäiset sanat. Vaihtojen kokonaismäärään laskettiin siirtymät klusterista toiseen, siirtymät klusterista yksittäiseen sanaan ja myös siirtymät yksittäisten sanojen välillä. Lisäksi laskettiin kategorian ulkopuolisten sanojen määrä, toistettujen sanojen määrä ja toistoprosentti (toistettujen sanojen osuus kokonaissanamäärästä). Tutkittavien minuutin pituinen suoritus jaettiin vielä neljään 15 sekunnin pituiseen neljännekseen, ja jokaisesta neljänneksestä laskettiin oikein tuotettujen sanojen määrä. Sanan osuessa neljänneksien rajalle se laskettiin kuuluvaksi siihen neljännekseen, johon sanasta kuului suurin osa, mikä varmennettiin Praat-ohjelman avulla.

Analyysin reliabiliteetti oli korkea. Laadullisen klusteroinnin teki kaksi tutkijaa, jotka ensin sopivat alustavista klusterointiperiaatteista aiemman tutkimuskirjallisuuden perusteella. Sen jälkeen he klusteroivat aineiston 
litteraattien ja video-audioaineiston avulla itsenäisesti. Klusterointiratkaisujen yksimielisyys oli $81 \%$. Eriäviin ratkaisuihin etsittiin keskustellen yhteisymmärrys. Määrälliset tunnusluvut (sanojen kokonaismäärä, toistot ja intruusiot) tutkijat laskivat $100 \%$ :n yksimielisyydellä.

\subsection{Tilastollinen analyysi}

Aineisto analysoitiin IBM SPSS Statistics (Version 25) -ohjelmalla. Shapiro-Wilkin -testin mukaan jakaumat olivat vinoja, minkä vuoksi käytettiin epäparametrisia testejä. Mann-Whitneyn U-testillä tarkasteltiin iän ja sukupuolen osuutta tehtävästä suoriutumiseen. Tutkittavat jaettiin iän mukaan kahteen yhtä suureen ryhmään; 80-84-vuotiaat $(n=15)$ ja $85-92$-vuotiaat $(n=15)$. Koulutuksen osuutta tuloksiin analysoitiin KruskallWallisin testillä. Sujuvuusmuuttujien välisiä yhteyksiä arvioitiin Spearmanin järjestyskorrelaatiokertoimen avulla.

Tilastollisesti merkitseväksi määriteltiin $p$ arvo $<0,05$. Korrelaatiokertoimen arvo $r \geq$ 0,7 tarkoittaa tässä tutkimuksessa voimakasta riippuvuutta, $r<0,7 \geq 0,3$ kohtalaista tai merkittävää ja $r<0,3$ heikkoa riippuvuutta (Tähtinen, Laakkonen \& Broberg, 2011, s. 141).

\section{TULOKSET}

Tutkittavat tuottivat minuutin aikana keskimäärin 18 erilaista eläintä tarkoittavaa sanaa. Vaihteluväli oli laaja (10-29), mutta $75 \%$ tutkittavista tuotti korkeintaan 21 eri eläinsanaa (Taulukko 2). Aineistosta erottui 11 semanttista alakategoriaa: kotipiirin eläimet, tuotantoeläimet, linnut, Suomen luonnonvaraiset eläimet, hyönteiset, eksoottiset eläimet, kalat, jyrsijät, petoeläimet, hirvieläimet ja kavioeläimet. Näistä alakategorioista muodostuneita klustereita puhujilla oli tehtävässä keskimäärin 4 (vaihteluväli 2-8) ja vaihtoja 3,8 (vaihteluväli 1-8). Klustereiden koko oli keskimäärin 3,52 sanaa (vaihteluväli 1,389,00). Puhujien enemmistö (75\%) tuotti korkeintaan neljä sanaa klusteria kohden. 
TAULUKKO 2. Yhteenveto sanasujuvuustehtävän tuloksista.

\begin{tabular}{|l|l|l|l|l|l|l|}
\hline & $\begin{array}{l}\text { Keski- } \\
\text { arvo }\end{array}$ & $\begin{array}{l}\text { Keski- } \\
\text { hajonta }\end{array}$ & $\begin{array}{l}\text { Vaihtelu- } \\
\text { väli }\end{array}$ & $\begin{array}{l}\mathbf{2 5 .} \\
\text { persentiili }\end{array}$ & $\begin{array}{l}\mathbf{5 0 .} \\
\text { persentiili }\end{array}$ & $\begin{array}{l}75 . \\
\text { persentiili }\end{array}$ \\
\hline $\begin{array}{l}\text { Oikein tuotettujen } \\
\text { sanojen määrä }\end{array}$ & 18,23 & 4,48 & $10-29$ & 15 & 17 & 21 \\
\hline Sanojen kokonaismäärä & 19,57 & 4,48 & $12-34$ & 16 & 18,50 & 21,25 \\
\hline $\begin{array}{l}\text { 1.neljänneksen } \\
\text { sanamäärä }\end{array}$ & 8,07 & 2,16 & $4-13$ & 6,75 & 8 & 10 \\
\hline $\begin{array}{l}\text { 2.neljänneksen } \\
\text { sanamäärä }\end{array}$ & 3,73 & 2,07 & $0-10$ & 2,75 & 4 & 4,25 \\
\hline $\begin{array}{l}\text { 3.neljänneksen } \\
\text { sanamäärä }\end{array}$ & 3,07 & 1,93 & $0-8$ & 1,75 & 3 & 4,25 \\
\hline $\begin{array}{l}\text { 4.neljänneksen } \\
\text { sanamäärä }\end{array}$ & 3,13 & 2,05 & $0-8$ & 1,75 & 3 & 5 \\
\hline KIusterien määrä & 4,07 & 1,53 & $2-8$ & 3 & 4 & 5 \\
\hline Klusterin keskiarvokoko & 3,52 & 1,97 & $1,38-9,0$ & 2,15 & 3 & 4,13 \\
\hline Vaihtojen määrä & 3,80 & 2,01 & $1-8$ & 2 & 3 & 5,25 \\
\hline Toiston määrä & 1,33 & 1,75 & $0-7$ & 0 & 1 & 2 \\
\hline Toistoprosentti & 6,5 & 8,5 & $0-33$ & 0 & 4,3 & 10,25 \\
\hline Intruusiot & 0 & 0 & 0 & 0 & 0 & 0 \\
\hline
\end{tabular}

Toistettujen sanojen määrän keskiarvo oli 1,3 ja toistojen osuuden keskiarvo $6,5 \%$. Toistettujen sanojen määrän ja tuotettujen sanojen kokonaismäärän välillä oli heikko positiivinen yhteys $(r=.36$; $p=.05)$. Toistoja tuotti kuitenkin vain 17 puhujaa ( $57 \%$ ) yhteensä 40 kertaa. He toistivat keskimäärin 2,4 sanaa (vaihteluväli $1-7$ ), ja toistettujen sanojen osuus kaikista sanoista oli heillä $11,4 \%$. Toistettu sana tuli 26 kertaa esille myöhemmin suorituksen aikana (toistava perseveraatio), ja 14 kertaa sama sana toistui heti ensimaininnan jälkeen (jatkuva perseveraatio). Toiston määrällä ei ollut yhteyttä tutkimuksen taustamuuttujiin tai tuotettujen sanojen määrään. Edelliseen tehtävänantoon juuttumista (juuttuva perseveraatio) aineistossa ei ilmennyt lainkaan. Tutkimushenkilöt eivät myöskään tuottaneet annetun kategorian (eläimet) ulkopuolisia sanoja, eli heillä ei esiintynyt lainkaan intruusioita.

Mitä enemmän tutkittava tuotti sanoja oikein, sitä enemmän hänellä oli myös klus- tereita $(r=.60 ; p<.001)$ ja vaihtoja $(r=.57$; $p=.001)$. Sanojen kokonaismäärän ja klustereiden määrän $(r=.71 ; p<.001)$ sekä kokonaismäärän ja vaihtojen määrän $(r=.70 ; p<$ $.001)$ välillä oli myös positiivinen yhteys. Kun klustereiden määrä lisääntyi, myös vaihtojen määrä kasvoi $(r=.93 ; p<.001)$. Sen sijaan klustereiden keskiarvokoko pieneni merkitsevästi klustereiden määrän $(r=-.71 ; p<.001)$ ja vaihtojen määrän kasvaessa $(r=-.78$; $p<$ $.001)$.

Sanoista $44 \%$ tuotettiin ensimmäisen neljänneksen aikana ja $21 \%$ toisen neljänneksen aikana, eli puhujat tuottivat $65 \%$ sanoista jo ensimmäisen puolen minuutin aikana. Kolmannen ja neljännen neljänneksen osuudet olivat samansuuruiset (17\%). Yhden sanan neljänneksiä ilmeni koko aineistossa yhdeksän kertaa: toisessa neljänneksessä kahdesti, kolmannessa kolmesti ja neljännessä neljästi. Kokonaan tyhjiä neljänneksiä ilmeni aineistossa vain neljä kertaa. 
Nuorempi ikäryhmä (80-84-vuotiaat) tuotti enemmän sanoja oikein kuin vanhempi (85-92-vuotiaat) $(Z=-2,014 ; p=.045)$. Ikäryhmien muut tulokset eivät eronneet toisistaan. Miesten ja naisten tuloksissa ei myöskään ilmennyt eroja, eivätkä koulutustason perusteella muodostetut ryhmät eronneet toisistaan.

\section{POHDINTA}

Tarkastelimme tässä tutkimuksessa 80-92-vuotiaiden subjektiivisesti arvioituna neurologisesti terveiden suomenkielisten puhujien kielelliskognitiivisia taitoja semanttisen sanasujuvuuden tehtävässä (kategoria eläimet). Tulosten mukaan ikä vaikuttaa suoriutumiseen, mutta tuotettujen sanojen kokonaismäärä ja oikein tuotettujen sanojen määrä vaihtelivat kuitenkin suuresti. Tulokset osoittivat myös, että sanojen toistaminen oli varsin tavallista tämän ikäisille tehtävän aikana, mutta kategorian ulkopuolisia sanoja he eivät tuottaneet.

\subsection{Tulosten tarkastelu}

Tässä tutkimuksessa tutkimushenkilöt tuottivat oikein keskimäärin 18 sanaa, mutta oikeiden sanojen määrä vaihteli huomattavasti (vaihteluväli 10-29). Tulos on hyvin lähellä Pekkalan (2004) tutkiman nuoremman (60-76-vuotiaiden) joukon keskiarvoa 18,9. Toisaalta Alantien, Makkosen, Tyrkön, Oksan ja Korpijaakko-Huuhkan (2019) iäkkäiden (80-100-vuotiaiden) tutkittavien sanamäärien keskiarvo 21 on sama kuin tämän tutkimuksen 75. persentiiliarvo. Jos normaalisuorituksen alarajana pidetään aineiston alaneljänneksen (25. persentiilin) arvoa 15 (sanaa), yli 80-vuotiaiden suomalaisten tyypillinen suoritus eläinkategorian sanasujuvuustestissä asettuu välille 15-21 sanaa minuutissa. Tyypillisesti ikääntyneiden yli 80-vuotiaiden puhujien sanasujuvuussuoritus voi siis jäädä alle WAB-testin 20 sanan kriteerin (Pietilä ym., 2005).
Iän myötä semanttisen sanasujuvuuden tehtävässä tuotettujen sanojen kokonaismäärä laskee jonkin verran (Kim ym., 2019; Taler ym., 2019; Tallberg ym., 2008; Tombaugh ym., 1999). Tässäkin tutkimuksessa nuoremman tutkittavien joukon sanamäärä oli suurempi kuin vanhemman osajoukon, mutta tuotettujen sanojen kokonaismäärä vaihteli ryhmissä yksilöllisesti (myös Alantie ym., 2019). Suuri yksilöllinen vaihtelu ilmentääkin olennaisella tavalla yhtä ikääntymisen peruspiirrettä - ikääntyvien ihmisten suorituskyvyn lisääntyvää erilaisuutta (Hautala, 2013, s. 13; Ruoppila, 2010; Ylikoski ym., 1999). Tämän vuoksi myös kliinisten testien, kuten WAB-testin, ikätyypillisen vaihtelun rajat tulisi kartoittaa tarkemmin.

Erilaisia klustereita tutkimamme ikäihmiset tuottivat keskimäärin 4 (vaihteluväli 2-8) ja vaihtoja keskimäärin 3,8 (vaihteluväli 1-8). Tulos kertoo varsin joustavasta ja saumattomasta kielelliskognitiivisesta prosessoinnista (Troyer ym., 1997). Pekkalan (2004, s. 101) tutkimuksessa suomenkieliset 60-76-vuotiaat puhujat tuottivat vain vähän enemmän klustereita (keskimäärin 5) ja vaihtoja $(4,9)$ kuin tämän tutkimuksen iäkkäämmät puhujat. Tämä oli odotettavissa, koska tuotettujen sanojen määrässäkin oli samansuuntainen ero.

Tutkittavien joustavasta sanahausta kertoo myös se, että klusterien keskikoko (3,5 sanaa) oli varsin suuri ja suurempi verrattuna aiempiin tutkimuksiin. Niissä klusterien keskikoko on vaihdellut noin yhdestä (1,01 Haugrud ym., 2011; 1,1 Troyer ym., 1998) liki kolmeen (2,8 Pekkala, 2004; 2,5 Wajman, Cecchini, Bertolucci \& Mansur, 2018), ja kaikissa niissä tutkittavat ovat olleet nuorempia kuin tämän tutkimuksen puhujat. Tulosten erot johtunevat erilaisista painotuksista klusterointiratkaisuissa.

Tässä tutkimuksessa kaikki puhujat pysyivät annetussa eläinkategoriassa eli intruusioita ei ilmennyt. Myös Pekkalan (2004, s.169) mukaan eläinkategoriassa ilmenee erittäin vä- 
hän intruusioita. Intruusioiden puute kertoo, että tutkittavan työmuisti ja toiminnanohjaus toimivat riittävän tehokkaasti yhdessä, mikä mahdollistaa aktivoituvan, mutta tehtävän kannalta epäolennaisen, kielellisen aineksen inhiboinnin (Hasher \& Zacks, 1988; Shao, ym., 2014; Zacks \& Hasher, 1997). Intruusioiden puuttuminen voi olla osoitus myös siitä, että tyypillisesti ikääntyneiden ihmisten mentaalileksikossa sanaedustumat säilyvät eheinä, vaikka pääsy niihin voi edustumien välisten yhteyksien heikentymisen vuoksi iän myötä hankaloitua (Burke \& Graham, 2012; Burke \& Shafto, 2004; Kavé \& Goral, 2017).

Toistojen osuus tutkimuksemme koko aineistosta oli keskimäärin $6,5 \%$, mikä on selvästi enemmän kuin nuorempia puhujia koskevissa tutkimuksissa. Pitkäsen (2019) 70-80-vuotiailla ${ }^{2}$ tutkittavilla $(N=50)$ toistojen osuus oli 2,9\%, kun se laskettiin yhteensä kolmen semanttisen, kahden foneemisen ja yhden verbikategorian tehtävän tuloksesta. Tutkimuksessa, jossa terveet puhujat $(N=180)$ edustivat kattavasti aikuisikää (18$82 \mathrm{v}$ ), keskimääräinen toistoprosentti eläinkategorian tehtävässä oli 1,28, mutta korkea ikä lisäsi merkitsevästi toistojen osuutta (Woods ym., 2016). Toistojen määrän onkin osoitettu kasvavan iän karttuessa, tosin varsin hitaasti (Azuma, 2004; Pekkala, 2004; Suhr \& Jones, 1998). Tuloksemme vahvistaa tätä näkemystä.

Toisto ei kuitenkaan ole tyypillistä kaikille ikääntyneille. Tutkimuksessamme vain hiukan yli puolet puhujista (17/30) toisteli sanoja. Yhteensä 40 toistokerrasta 26:ssa toistettu sana esiintyi myöhemmin suorituksen aikana (toistuva perseveraatio), mitä pidetäänkin tyypillisimpänä toiston muotona terveillä tutkimushenkilöillä (Azuma, 2004; Pekkala, ym., 2008; Ramage ym., 1999). Puhujan työmuisti todennäköisesti kuormittuu tehtävän

\footnotetext{
${ }^{2}$ Pitkäsen (2019) tutkimien ikäryhmien (70-ja 80-vuotiaat) tulokset eivät eronneet tilastollisesti merkitsevästi toisistaan.
}

aikana, ja oman puheen monitorointi pettää, jolloin puhuja tuottaa saman sanan uudelleen (Abrams \& Farrell, 2010; Cowan, 2010). Monitoroinnin pettäminen vaikutti olevan kuitenkin hetkellistä, koska tutkittavat pystyivät toiston jälkeen jatkamaan suoritusta. Ajattelemme tämän ilmentävän työmuistin ja eksekutiivisten toimintojen tehokasta yhteistyötä hetkellisestä kuormittumisesta huolimatta.

Aineistossa ilmeni 14 tapausta, joissa puhuja tuotti saman sanan kaksi kertaa peräkkäin (jatkuva perseveraatio). Tämä toiston muoto on nuoremmilla suomalaisilla puhujilla erittäin vähäistä (Pekkala ym., 2008). Pitkäsen (2019) 70-80-vuotiaiden ryhmässä sen osuus kaikista tuotetuista sanoista oli vain $0,1 \%$, eikä esimerkiksi Ramage kumppaneineen (1999) havainnut tällaista toistoa lainkaan terveillä puhujilla sanasujuvuustehtävässä. Arvioimmekin, että sanan toisto voi olla tutkittavan apukeino, jolla hän kiinnittää oman tarkkaavuutensa tehtävään ja ilmaisee sekä itselleen että kuulijalle pitävänsä tehtävän käynnissä (Penttilä, Korpijaakko-Huuhka \& Kent, 2019).

Tutkimuksessamme kukaan ei juuttunut aiempaan toimintaan tai edelliseen tehtävänantoon (juuttuva perseveraatio). Tämä johtunee siitä, että WAB-testissä sanasujuvuustehtävää edeltää erilainen tehtävä (esineiden nimeäminen), toisin kuin esimerkiksi Pekkalan ym. (2008) Alzheimerin tautia koskevassa tutkimuksessa, jossa tutkittavat tekivät useita sanasujuvuustehtäviä peräkkäin. Mitä pitemmälle puhujan sairaus oli edennyt, sitä useammin hän juuttui edelliseen tehtävänantoon. Tämä toiston muoto voisikin indikoida iäkkään ihmisen kielelliskognitiivisten kykyjen patologisia muutoksia.

Tässä tutkimuksessa puhujien tuottamat sanat jakautuivat minuutin neljänneksille siten, että lähes puolet ( $44 \%)$ sanoista tuotettiin jo ensimmäisen 15 sekunnin aikana ja viidesosa (21\%) toisen neljänneksen aikana. 
Tutkittavat onnistuivat tuottamaan sanoja tehtävän loppuun asti, vaikka sanojen tuotto hidastuikin kahden viimeisen neljänneksen aikana (myös Crowe, 1997; Demetriou \& Holzer, 2017). Tutumpien ja yleisimpien sanojen hakemisen pitäisikin olla helpointa juuri tehtävän alussa (Demetriou \& Holzer 2017; Fernaeus \& Almkvist, 1998; Raboutet ym., 2010). Tässä tutkimuksessa osalla tutkittavista tehtävä lähti kuitenkin käyntiin hiukan tehottomasti ensimmäisessä neljänneksessä, ja tuotto myös hiipui selvästi kohti loppua; sanamääräkin jäi siten alhaiseksi. Saman työläyden havaitsivat myös Demetriou ja Holzer (2017), kun he arvioivat vastaavassa tehtävässä sellaisten henkilöiden suoriutumista, joilla oli todettu lievä kognitiivinen heikentyminen (ks. Petersen ym., 2001). Havaintomme herättääkin kysymyksen: onko sanojen työläs tuottaminen erityisesti sanasujuvuustehtävän alussa merkki siitä, että niukasti sanoja tuottavat puhujat ovat siirtymässä normaalista ikääntymisestä kohti lievää kognitiivista heikentymistä?

Tässä tutkimuksessa ei havaittu tutkittavien sukupuolen tai koulutustason liittyvän sanasujuvuustehtävästä suoriutumiseen. Sen sijaan tutkimuksemme nuoremmat osallistujat tuottivat enemmän eri eläimiä tarkoittavia sanoja kuin vanhemmat. Korkean iän onkin havaittu vähentävän oikein tuotettujen sanojen määrää semanttisessa sanasujuvuustehtävässä (Brickman ym., 2005; Tombaugh ym., 1999; Troyer ym., 1997). Tyypillisesti ikääntyneet ihmiset itsekin nimeävät sananlöytämisen vaikeudet usein yleisimmäksi ikääntymiseen liittyväksi kielelliskognitiiviseksi muutokseksi (Burke \& Shafto, 2004).

\subsection{Menetelmän arviointi}

Tähän tutkimukseen osallistuneet henkilöt olivat tyypillisesti ikääntyneitä, oman arvionsa mukaan neurologisesti terveitä ihmisiä, jotka asuivat pienellä maantieteellisellä alueella
Etelä-Suomessa. Tutkittavat saattavat edustaa varsin poikkeuksellista otosta ikäryhmästään (supranormals, Brickman ym., 2005), sillä jokainen heistä asui tutkimushetkellä omassa kodissaan maaseudulla viettäen omatoimista elämää (Suomen yli 80-vuotiaiden populaatiosta ks. Helminen ym., 2017, s. 51). Tutkimuksemme tuloksen yleistettävyyttä heikentää luonnollisesti myös se, että tutkittavia oli vain 30 .

Tutkimusaineiston keräsi yksi tutkija, ja tehtävänanto oli jokaisen tutkimushenkilön kohdalla täsmälleen samanlainen. Itse semanttinen sanasujuvuustehtävä on laajasti käytetty ja herkkänä pidetty neuropsykologinen testi (Henry \& Crawford, 2004; Wajman ym., 2018). Erityisesti eläinten luettelemistehtävän tulosta pidetään pätevänä ja vertailun mahdollistavana mittarina, koska tutkimushenkilöiden taustamuuttujat, kuten kotimaa, kulttuuri, kieli, koulutus tai tiettyyn sukupolveen kuuluminen, aiheuttavat vähäisempiä suorituseroja kuin moni muu kategoria (Ardila ym., 2006; Pekkala ym., 2009). Tutkimuksen aineiston keruuta voidaan pitää luotettavana.

Aineisto analysoitiin pääasiassa kansainvälisesti paljon käytetyn Troyerin ym. (1997) laskentamallin mukaan. Siitä poiketen hyväksyimme eri sanoiksi eläinten alakategorian nimen lisäksi saman kategorian iältään ja sukupuoleltaan eri yksilöitä tarkoittavat sanat, koska halusimme ottaa huomioon tutkimukseen osallistuneiden ihmisten elinpiirin, siis sen, kuinka he ovat oppineet eri eläimiä kategorisoimaan arjessaan. Tämä lisäsi hieman sanamääriä ja klustereiden kokoa, mutta tuloksemme ovat verrattavissa tutkimuksiin, joissa on käytetty samaa laskentatapaa kuin tässä tutkimuksessa (Kavé ym., 2008; Tallberg ym., 2008). Määrälliset tunnusluvut (sanojen kokonaismäärä, toistot ja intruusiot) olivat helposti laskettavissa, ja tutkijoiden välinen reliabiliteetti oli korkea. Sanojen välisten 
merkityssuhteiden tarkastelu eli klusterointi edustaa parhaimmillaankin tutkijan subjektiivista tulkintaa tutkimushenkilön tuottamista semanttisista alakategorioista (Body \& Muskett, 2013; Muskett ym. 2013). Sitä indikoi laadullisen analyysin alhaisempi reliabiliteetti. Parhaan laskentatavan selvittäminen vaatiikin jatkotutkimusta.

\subsection{Kliiniset johtopäätökset}

Tämän tutkimuksen tarkoitus on ollut lisätä tietoa tyypillisesti ikääntyneiden ihmisten kielelliskognitiivisista kyvyistä ja niiden muutoksista arvioimalla heidän suoriutumistaan eläimiä tarkoittavien sanojen mieleenpalautustehtävässä. Tietoa sanahaun sujumisesta tarvitaan, jotta voidaan erottaa toisistaan tyypilliset ja poikkeavat kielelliskognitiiviset muutokset nykyistä varhaisemmassa vaiheessa ja luotettavammin sekä tiedon karttumisen myötä tukea ikääntyneiden ihmisten kommunikointikykyä (Korpijaakko-Huuhka \& Klippi, 2017; Pekkala, 2011).

Vaikka tuloksemme perustuvat vain yhteen tehtävään, ne täydentävät toistaiseksi varsin

\section{LÄHTEET}

Abrams, L. \& Farrell, M. T. (2010). Language processing in normal Aging. Teoksessa J. Guendouzi, F. Loncke \& M.J. Williams (toim.), The handbook of psycholinguistic and cognitive processes. Perspectives in communicative disorders (s. 49-74). New York: Psychology Press.

Alantie, S., Makkonen, T., Tyrkkö, J., Oksa, A. \& Korpijaakko-Huuhka, A.-M. (2019). Semantic and phonological verbal fluency in very old Finnish speakers. Posteri-esitelmä. Nordic Aphasia Conference. Turku, kesäkuu 2019.

Albert, M. L. \& Sandson, J. (1986). Perseveration in aphasia. Cortex, 22, 103-115.

Ansado, J., Marsolais, Y., Methqal, I., Alary, F. \& Joanette, Y. (2013). Review - the adaptive aging brain: evidence from the preservation of communication abilities with age. European Journal of Neuroscience, 37, 1887-1895. niukkaa tietoa erittäin iäkkäiden suomenkielisten puhujien tyypillisistä kielellisistä taidoista, erityisesti suoriutumisesta semanttisessa sanasujuvuustehtävässä (ks. Alantie ym., 2019; Kontiola ym., 1990; Pitkänen, 2019). Tutkimuksemme tulosten perusteella ikäihmisen kielellisiä kykyjä tulisi arvioida tavanomaista tarkemmin, mikäli eläinsanojen mieleenpalauttamistehtävässä oikein tuotettujen sanojen kokonaismäärä jää alle 15 sanan tai esiintyy annetun kategorian ulkopuolisia sanoja eli intruusioita.

Tutkimuksemme tuo esiin tarpeen kerätä suurempi normatiivinen aineisto, joka edustaisi mahdollisimman hyvin Suomen ikääntynyttä väestöä. Tätä tutkimusta täydentävä laajempi aineisto voisi tuottaa ikäihmisten kanssa työskenteleville puheterapeuteille luotettavat erotusdiagnostiset suuntaviivat, joiden avulla tyypilliset kielelliskognitiiviset muutokset olisivat erotettavissa kielelliskognitiivisten kykyjen lievästä heikentymisestä ja patologisista muutoksista.

Ardila, A., Ostrosky-Solís, F. \& Bernal, B. (2006). Cognitive testing toward the future: the example of semantic verbal fluency (animals). International Journal of Psychology, 41, 324332.

Azuma, T. (2004). Working memory and perseveration in verbal fluency. Neuropsychology, $18,69-77$.

Body, R. \& Muskett, T. (2013). Pandas and penguins, monkeys and caterpillars: Problems of cluster analysis in semantic verbal fluency. Qualitative Research in Psychology, 10, 28-41.

Boersma, P. \& Weenik, D. (2005): Praat: Doing phonetics by computer [Computer program]. Version 6.0.04, haettu internetistä osoitteesta: http://www.praat.org/

Braver, T.S. \& West, R. (2008). Working memory, executive control, and aging. Teoksessa F. I. M. Craik \& T. A. Salthouse (toim.), The handbook of aging and cognition (third edition), (s. 311372). New York: Psychology Press. 
Brickman, A. M., Paul, R. H., Cohen, R. A., Williams, L. M., MacGregor, K. L., Jefferson, A. L. \& ...Gordon, L. (2005). Category and letter verbal fluency across the adult life span: relationship to EEG theta power. Archives of Clinical Neuropsychology, 20, 561-573.

Burke, D. M. \& Graham, E. R. (2012). The neural basis for aging effects on language. Teoksessa M. Faust (toim.), The handbook of the neuropsychology of language (s. 778-800). New Jersey: Blackwell Publishing.

Burke, D. M. \& Shafto, M. A. (2008). Language and aging. Teoksessa F. Craik \& T. Salthouse (toim.), The handbook of aging and cognition (s. 373-443). New York: Psychology Press.

Cahana-Amitay, D. \& Albert, M. L. (2014). Brain and language: Evidence for neural multifunctionality. Behavioural Neurology, 28, $1-16$.

Capitani, E., Laiacona, M. \& Barbarotto, R. (1999). Gender affects word retrieval of certain categories in semantic fluency tasks. Cortex, 35 , 273-278.

Capitani, E., Laiacona, M. \& Basso, A. (1998). Phonetically cued word-fluency, genderdifferences and aging: A reappraisal. Cortex, 34, 779-783.

Cowan, N. (2010). Working memory and attention in language use. Teoksessa J. Guendouzi, F. Loncke \& M. Williams (toim.), The handbook of psycholinguistic and cognitive processes. Perspectives in communicative disorders (s. 75-97). New York: Psychology Press.

Crowe, S. F. (1998). Decrease on the performance on the verbal fluency test as a function of time: Evaluation in a young healthy sample. Journal of Clinical and Experimental Neuropsychology, 20,391-401.

Demetriou, E. \& Holtzer, R. (2017). Mild cognitive impairments moderate the effect of time on verbal fluency performance. Journal of the International Neuropsychological Society, 23, 44-55.

Dennis, N.A. \& Cabeza, R. (2008). Neuroimaging of healthy cognitive aging. Teoksessa F. Craik \& T. Salthouse (toim.), The handbook of aging and cognition (third edition), (s. 1-54). New York: Psychology Press.

Eurostat (2016). Population structure and ageing. Haettu internetistä osoitteesta: https:// ec.europa.eu/eurostat/statistics-explained/ index.php/Population_structure_and_ageing
Eurostat (2019). Population structure and ageing. Haettu internetistä osoitteesta: https:// ec.europa.eu/eurostat/statistics-explained/ index.php/Population_structure_and_ageing

Fernaeus, S. \& Almkvist, O. (1998). Word production: Dissociation of two retrieval modes of semantic memory across time. Journal of Clinical and Experimental Neuropsychology, 20, 137-143.

Fjell, A.M., Evoy, L., Holland, D., Dale, A. M. \& Wavhovd, K. B. (2014). What is normal in normal aging? Effects of aging, amyloid, and Alzheimer's disease on the cerebral cortex and the hippocampus. Progress in Neurobiology, 117, 20-40.

Goñi, J., Arrondo, G., Sepulcre, J., Martincorena, I., Vélez de Mendizábal, N., Corominas-Murtra, B., ... \& Villoslada, B. (2011). The semantic organization of the animal category: Evidence from semantic verbal fluency and network theory. Cognitive Processing, 12, 183-196.

Gruenewald, P. J. \& Lockhead, G. R. (1980). The free recall of category examples. Journal of Experimental Psychology: Human Learning \& Memory, 6, 225-240.

Haugrud, N., Crossley, M. \& Vrbancic, M. (2011). Clustering and switching strategies during verbal fluency performance differentiate Alzheimer's disease and healthy aging. Journal of the International Neuropsychological Society, 17, 1153-1157.

Hasher, L. \& Zacks, R. T. (1988). Working memory, comprehension and aging: A review and a new view. The Psychology of Learning and Motivation, 22, 193-225.

Hautala, T. (2013). Ikääntyneiden kuuntelijoiden puheen ymmärtäminen kognitiivisesti vaativassa tilanteessa. Väitöskirja. Oulu: Acta Universitatis Ouluensis, B 114.

Helminen, V., Vesala, S., Rehunen, A., Strandell, A., Reimi, P. \& Priha, A. (2017). Ikääntyneiden asuinpaikat nyt ja tulevaisuudessa. Suomen ympäristökeskuksen raportteja 20/2017.

Henry, J. D. \& Crawford, J. R. (2004). A metaanalytic review of verbal fluency performance following focal cortical lesions. Neuropsychology, $18,284-295$.

Hoffman, P. \& Lambon Ralph, P. A. (2013). Shapes, scents and sounds: Quantifying the full multi-sensory basis of conceptual knowledge. Neuropsychologia, 51, 14-25. 
Hursti, M. (2018). Tyypillisesti ikä̈ntyneiden erittäin vanhojen pubujien sananlöytämisvaikeudet sarjakuvakerronnassa. Monitapaustutkimus. Logopedian kandidaatintutkielma. Tampereen yliopisto.

Kavé, G. (2005). Phonemic fluency, semantic fluency, and difference scores: Normative data for adult Hebrew speakers. Journal of Clinical and Experimental Neuropsychology, 27, 690699.

Kavé, G. \& Goral, M. (2017). Do age-related word retrieval difficulties appear (or disappear) in connected speech? Aging, Neuropsychology, and Cognition, 24, 508-527.

Kavé, G., Kigel, S. \& Kochva, R. (2008). Switching and clustering in verbal fluency tasks throughout childhood. Journal of Clinical and Experimental Neuropsychology, 30, 349-359.

Kemper, S. \& Kemtes, K. (2000). Aging and message production and comprehension. Teoksessa D. C. Parks \& N. Schwartz (toim.), Cognitive aging: A primer (s. 197-214). New York: Psychology Press.

Kim, N., Kim, J.-H., Wolters, M., MacPherson, S. \& Park, J. C. (2019). Automatic Scoring of Semantic Fluency. Frontiers in Psychology. Haettu internetistä osoitteesta: https://doi. org/10.3389/fpsyg.2019.01020

Kontiola, P., Laaksonen, R., Sulkava, R. \& Erkinjuntti, T. (1990). Pattern of language impairment is different in Alzheimer's disease and multi-infarct dementia. Brain and Language, 38, 364-383.

Korpijaakko-Huuhka, A.-M. \& Klippi, A. (2010). Ikääntyminen ja viestintä. Teoksessa P. Korpilahti, O. Aaltonen \& M. Laine (toim.), Kieli ja aivot (s. 264-269). Turku: Turun yliopisto.

Korpijaakko-Huuhka, A.-M. \& Klippi, A. (2017). Ikääntyminen, viestintä ja muistisairaudet. Teoksessa A. Klippi, A.-M. KorpijaakkoHuuhka, M. Lehtihalmes \& P. Rautakoski (toim.), Afasia. Aikuisiän kielihäiriöiden aivoperusta ja kuntoutus (s. 65-83). Helsinki: Gaudeamus.

Levelt, W. J. M. (1989). Speaking: From intention to articulation. Cambridge, Massachusetts: The MIT Press.
Lopes, M., Brucki, S. M. D., Giampaoli, V. \& Mansur, L. L. (2009). Semantic verbal fluency test in dementia: Preliminary retrospective analysis. Dementia \& Neuropsychologia, 3, 315-320.

Marini, A. \& Andreetta, S. (2016). Age-related effects on language production: A combined psycholinguistic and neurolinguistic perspective. Teoksessa H. Harris Wright (toim.), Cognition, Language, and Aging (s. 51-80). Amsterdam / Philadelphia: John Benjamins Publishing Company.

Maxim, J. \& Bryan, K. (1994). Language of the elderly: A clinical perspective. London: Whurr.

Mayr, U. (2002). On the dissociation between clustering and switching in verbal fluency: comment on Troyer, Moscovitch, Winocur, Alexander and Stuss. Neuropsychologia, 40, 562-566.

Mortensen, L., Meyer, A. \& Humpreys, G. W. (2007). Age-related effects on speech production: A review. Language and Cognitive Processes, 21, 238-290.

Moses, M. S., Nickels, L. A. \& Sheard, C. (2007). Chips, cheeks and carols: A review of recurrent perseveration in speech production. Aphasiology, 21, 960-974.

Muskett, T., Body, R. \& Perkins, M. (2013). A discursive psychology critique of semantic verbal fluency assessment and its interpretation. Theory \& Psychology, 23, 205-226.

Nicholas, M., Connor, L. T., Obler, L. K. \& Albert, M. L. (1998). Aging, language and language disorders. Teoksessa M. Taylor Sarno (toim.), Aquired Aphasia. Third Edition (s. 413-440). San Diego: Academic Press.

Obler, L. K. \& Pekkala, S. (2008). Language and communication in aging. Teoksessa B. Stemmer \&. H. Whitaker (toim.), Handbook of the Neuroscience of Language (s. 351-356). London: Academic Press (Elsevier).

Pakhomov, S. V., Eberly, L. E. \& Knopman, D. S. (2018). Recurrent perseverations on semantic verbal fluency tasks as an early marker of cognitive impairment. Journal of Clinical and Experimental Neuropsychology, 40, 832-840.

Parjanne, M.-L. (2004). Väestön ikärakenteen mutoksen vaikutukset ja niihin varautuminen eri hallinnonaloilla. Sosiaali- ja terveysministeriön selvityksiä, 18. Helsinki: Sosiaali- ja terveysministeriö, 1-78. 
Pekkala, S. (2004). Semantic fluency in mild and moderate Alzheimer's disease. Väitöskirja. Helsinki: Helsingin yliopiston fonetiikan laitoksen julkaisuja 47.

Pekkala, S. (2011). Normaaliin ikääntymiseen liittyvät kielelliset muutokset ja niiden syyt. Gerontologia, 25, 35-43.

Pekkala, S. (2012). Verbal fluency task and the neuropsychology of language. Teoksessa M. Faust (toim.), The Handbook of the Neuropsychology of Language (s. 619-634). New Jersey: Blackwell Publishing.

Pekkala, S., Albert, M. L., Spiro III, A. \& Erkinjuntti, T. (2008). Perseveration in Alzheimer's disease. Dementia and Geriatric Cognitive Disorders, 25, (109-114.

Pekkala, S., Goral, M., Hyun J. M., Obler, L. K., Erkinjuntti, T., \& Albert, M. L. (2009). Verbal fluency in two contrasting languages. Clinical Linguistics \& Phonetics, 23, 431-445.

Penttilä, N., Korpijaakko-Huuhka, A. \& Kent, R. D. (2018). Tavallista sujumattomuutta: Aikuisten puheen sujuvuuden kvantitatiivinen analyysi. Puhe ja Kieli, 38, 153-173.

Petersen, R. C., Doody, R. D., Kurz, A., Mohs, R. C., Morris, J. C., Rabins, P. V., ... \& Winblad, B. (2001). Current concepts in mild cognitive impairment. Archives of Neurology, 58, 19851992.

Pietilä, M.-L., Lehtihalmes, M., Klippi. A. \& Lempinen, M. (2005). Western Aphasia Battery. Käsikirja. Suomenkielinen laitos. Helsinki: Psykologien kustannus Oy.

Pitkänen, E. (2019). Tyypillisesti ikääntyvien 70ja 80-vuotiaiden henkilöiden sanasujuvuus. Logopedian pro gradu -tutkielma. Oulun yliopisto.

Raboutet, C., Sauzéon, H., Corsini, M., Rodrigues, J., Langevin, S. \& N'Kaoua, B. (2010). Performance on a semantic verbal fluency task across time: Dissociation between clustering, switching, and categorical exploitation processes. Journal of Clinical and Experimental Neuropsychology, 32, 268-280.

Ramage, A., Bayles, K., Helm-Estabrooks, N. \& Cruz, R. (1999). Frequency of perseveration in normal subjects. Brain and Language, 66, 329-340.

Renvall, K. (2010). Nimeämivaikeuksien arviointi ja kuntoutus. Teoksessa P. Korpilahti, O. Aaltonen \& M. Laine (toim.), Kieli ja aivot (s. 321-329). Turku: Turun yliopisto.
Roca, M., Manes, F., Chade, A., Gleichgerrcht, E., Gershanik, O., Arévalo, G. G., ... \& Duncan, J. (2012). The relationships between executive functions and fluid intelligence in Parkinson's disease. Psychological Medicine, 42, 2445-2452.

Rosen, W. G. (1980). Verbal fluency in aging and dementia. Journal of Clinical Neuropsychology, 2, 135-146.

Ruff, R. M., Light, R. H., Parker, S. B. \& Levin, H. S. (1997). The psychological construct of word fluency. Brain and Language, 57, 394-405.

Ruoppila, I. (2010). Vanheneminen. Teoksessa J.E. Nurmi, T. Ahonen, H. Lyytinen, P. Lyytinen, L. Pulkkinen \& I. Ruoppila (toim.), Ihmisen psykologinen kehitys (s. 206-263). Helsinki: WSOYpro Oy.

Salthouse, T. A. (2009). When does age-related cognitive decline begin? Neurobiology of Aging, 30, 507-514.

Shao, Z., Janse, E., Visser, K. \& Meyer, A. S. (2014). What do verbal fluency tasks measure? Predictors of verbal fluency in older adults. Frontiers in Psychology, 5, 772-790.

Sandson, J. \& Albert, M. L. (1987). Perseveration in behavioral neurology. Neurology, 37, 17361741.

Stolwyk, R., Bannirchelvam, B., Kraan, C. \& Simpson, K. (2015). The cognitive abilities associated with verbal fluency task performance differ across fluency variants and age groups in healthy young and old adults. Journal of Clinical and Experimental Neuropsychology, 37, 70-83.

Suhr, J. A. \& Jones, R. D. (1998). Letter and semantic fluency in Alzheimer's, Huntington's, and Parkinson's dementias. Archives of Clinical Neuropsychology, 13, 447-454.

Sylvain-Roy, S., Lungu, O. \& Belleville, S. (2015). Normal aging of the attentional control functions that underlie working memory. The Journals of Gerontology, series B 70, 698-708.

Taler, V., Johns, B. T. \& Jones, M. N. (2019). A large-scale semantic analysis of verbal fluency across the aging spectrum: Data from the Canadian longitudinal study on aging. The Journals of Gerontology. Series B, Psychological Sciences and Social Sciences, doi:10.1093/ geronb/gbz003

Tallberg, I. M., Ivachova, E., Jones Tinghag, K. \& Östberg, P. (2008). Swedish norms for word fluency tests: FAS, animals and verbs. Scandinavian Journal of Psychology, 49, 479-485. 
Thornton, R. \& Light, L. L. (2006). Language comprehension and production in normal aging. Teoksessa J. Birren \& W. Schaie (toim.), Handbook of the psychology of aging (s. 261288). Burlington: Elsevier Academic Press.

Tombaugh, T. N., Kozak, J. \& Rees, L. (1999). Normative data stratified by age and education for two measures of verbal fluency: FAS and animal naming. Archives of Clinical Neuropsychology, 14, 167-177.

Troyer, A. K., Moscovitch, M. \& Winocur, G. (1997). Clustering and switching as two components of verbal fluency: Evidence from younger and older healthy adults. Neuropsychology, 11, 138-146.

Troyer, A. K., Moscovitch, M., Winocur, G., Leach, L. \& Freedman, M. (1998). Clustering and switching on verbal fluency tests in Alzheimer's and Parkinson's disease. Journal of the International Neuropsychological Society, 4, 137-143.

Troyer, A. K. (2000). Normative data for clustering and switching on verbal fluency tasks. Journal of Clinical and Experimental Neuropsychology, 22, 370-378.

Tröster, A. I., Salmon, D. P., McCullough, D. \& Butters, N. (1989). A comparison of the category fluency deficits associated with Alzheimer's and Huntington's disease. Brain and Language, 37, 500-513.

Tähtinen, J. \& Laakkonen, E. \& Broberg, M. (2011). Tilastollisen aineiston käsittelyn ja tulkinnan perusteita. Turun yliopiston kasvatustieteiden tiedekunnan julkaisuja C:20. Turku: Turun yliopiston kasvatustieteiden laitos ja Opettajan koulutuslaitos.

Vaughan, R., Coen, R., Kenny, R. A. \& Lawlor, B. A. (2016). Preservation of the semantic verbal fluency advantage in a large population-based sample: Normative data from the TILDA study. Journal of the International Neuropsychological Society, 22, 570-576.

Verhaegen, P. (2003). Aging and vocabulary scores: A meta-analysis. Psychology and Aging, 18, 332-339.

Wajman, J. R., Cecchini, M. A., Bertolucci, P. H. F. \& Mansur, L. L. (2018). Quanti-qualitative components of the semantic verbal fluency test in cognitively healthy controls, mild cognitive impairment, and dementia subtypes. Applied Neuropsychology: Adult, doi:10.1080/232790 95.2018.1465426
Whiteside, D. M., Kealey, T., Semla, M., Luu, H., Rice, L., Basso, M. \& Roper, B. (2016). Verbal fluency: Language or executive function measure? Applied Neuropsychology: Adult, 23, 29-34.

Wingfield, A. (2000). Speech perception and the comprehension of spoken language in adult aging. Teoksessa D. Park \& N. Schwartz (toim.), Cognitive Aging: A Primer (s. 175-195). Philadelphia: Psychology Press.

Wingfield, A. \& Stine-Morrow, E. A. L. (2000). Language and speech. Teoksessa F. Graik \& T. Salthouse (toim.), The Handbook of Aging and Cognition: Second Edition (s. 359-406). Mahwah: Laurence Erlbaum Associates.

Woods, D. L., Wyma, J. M., Herron, T. J. \& Yund, E. W. (2016). Computerized analysis of verbal fluency: Normative data and the effects of repeated testing, simulated malingering, and traumatic brain injury. Plos One, 11, e0166439.

Ylikoski, R., Ylikoski, A., Keskivaara, P., Tilvis, R., Sulkava, R. \& Erkinjuntti, T. (1999). Heterogeneity of cognitive profiles in aging: successful aging, normal aging and, individuals at risk for cognitive decline. European Journal of Neurology, 6, 645-652.

Zacks, R. T. \& Hasher, L. (1997). Cognitive gerontology and attention inhibition: A reply to Burke and McDowd. Journal of Gerontology: Psychological Sciences, 52B, 274-283.

Zarino, B., Crespi, M., Launi, M. \& Casarotti, A. (2014). A new standardization of semantic verbal fluency test. Neurological Sciences, 35, 1405-1411.

Östberg, P., Fernaeus, S., Hellström, Å., Bogdanović, N. \& Wahlund, L. (2005). Impaired verb fluency: A sign of mild cognitive impairment. Brain and Language, 95, 273-279. 


\section{SEMANTIC VERBAL FLUENCY IN TYPICALLY AGED NATIVE FINNISH SPEAKERS}

Niina Rinne, Sivupersoona Oy

Meri Hursti, Sivupersoona Oy

Anna-Maija Korpijaakko-Huuhka, Tampere University

Leena Rantala, Tampere University

In this study, we examined how 30 elderly Finnish speakers of 80-92 years old performed in a verbal fluency test. They were asked to name different animals for one minute. We counted the number of correctly produced words, semantic categories, switches, repetitions, and words falling outside the requested category. The performances were also evaluated in 15-second increments. Age, gender and education were examined as possible correlates of verbal fluency.

The participants produced averagely 18.2 words, over half of them (65\%) within the first 30 seconds. The younger participants (aged 80-84) produced a statistically significantly higher number of correct words than the older participants. The speakers did not produce words outside the requested category. The words grouped averagely into four semantic clusters including on average 3.5 words. The average proportion of repetitions was $6.5 \%$. The results show that when evaluating the verbal fluency of people older than 80 , special attention should be paid to the following: number of words produced correctly, words produced outside the requested category, and number and quality of repetitions.

Keywords: aging, language-cognitive skills, semantic verbal fluency, word search 
224 